\title{
TINGKAT KEPUASAN SISWA TERHADAP MENU MAKANAN YANG DISAJIKAN DALAM PENYELENGGARAAN MAKANAN DI SMP ISLAM TERPADU AL- FAHMI KOTA PALU 2019
}

\section{The Level of Student Satisfaction With The Food Service At Al-Fahmi Integrated Islamic Middle School In Palu City 2019}

\author{
Nurjaya, Wery Aslinda, Kasmawati \\ Poltekkes Kemenkes Palu \\ (jayajastal@yahoo.com, 081340846207)
}

\begin{abstract}
ABSTRAK
Penyelenggaraan makanan di sekolah kepada siswa berperan penting dalam rangka pencapaian status kesehatan yang optimal. Tujuan dari penelitian ini adalah untuk mengetahui tingkat kepuasan siswa terhadap menu makanan yang disajikan dalam penyelenggaraan makanan di SMP Islam Terpadu Al- Fahmi Kota Palu 2019. Penelitian ini merupakan jenis penelitian kualitatif dengan pendekatan deskriptif. Sampel dalam penelitian ini adalah total dari populasi yaitu semua siswa kelas 7 dan 8 yang berjumlah 95 orang di SMP Islam Terpadu Al Fahmi Kota Palu.Analisis data yang digunakan menggunakan analisis univariat.Analisis data dimulai dengan transkrip dan hasil wawancara mendalam. Hasil penelitian ini menunjukan bahwa dari 95 responden, 91,6\% menyatakan puas dengan rasa makanan yang disajikan. $89.5 \%$ menyatakan puas dengan penampilan makanan yang disajikan, $78.9 \%$ menyatakan puas dengan porsi makanan yang disajikan, $94.7 \%$ menyatakan puas dengan tingkat kematangan makanan yang disajikan, $87.4 \%$ menyatakan puas dengan kebersihan makanan yang disajikan. Kesimpulan dari penelitian ini adalah responden merasa puas terhadap makanan yang disajikan di SMP Islam Terpadu Al-Fahmi Kota Paluri. Saran dari penelitian ini sebaiknya dibuatkan ruang makan siswa dan membagi porsi makanan Agar semua siswa mendapatkan porsi makanan yang sama rata.
\end{abstract}

Kata kunci : Penyelenggaraan makanan, tingkat kepuasan

\section{ABSTRACT}

The provision of food service plays an important role in achieving optimal students health status in school. The purpose of this study is to determine the level of student satisfaction with food menus served in the organization of food at the Al-Fahmi Integrated Islamic Middle School in Palu City 2019. This research is a type of qualitative research with a descriptive approach. The sample in this study was the total of the population, namely all students in grades 7 and 8, amounting to 95 people in the Al Fahmi Integrated Islamic Middle School in Palu City. Data analysis used was univariate analysis. Data analysis began with transcripts and in-depth interviews. The results of this study indicate that of the 95 respondents, 91.6\% expressed satisfaction with the taste of the food served. $89.5 \%$ expressed satisfaction with the appearance of the food served, $78.9 \%$ expressed satisfaction with the portion of food served, $94.7 \%$ expressed satisfaction with the level of maturity of the food served, $87.4 \%$ expressed satisfaction with the cleanliness of the food served. The conclusion of this study was that respondents were satisfied with the food served at the Al-Fahmi Integrated Islamic Middle School in Paluri City. Suggestions from this study should make students' dining rooms and divide portions of food so that all students get equally even portions of food.

Keywords : Food service, Food Satisfaction Level 


\section{PENDAHULUAN}

Penyelenggaraan makanan institusi merupakan suatu pelayanan dimana penyelenggaran makanan disajikan dalam jumlah porsi besar atau banyak. Rangkaian kegiatan penyelenggaraan makanan di mulai dari perencanaan menu sampai dengan pendistribusian makanan kepada konsumen dalam rangka pencapaian status kesehatan yang optimal melalui pemberian makanan yang tepat dan termasuk kegiatan pencatatan, pelaporan, dan evaluasi (1). Tujuan utama penyelenggaraan makanan yaitu menyajikan suatu makanan dengan baik dan menarik agar konsumen merasa puas dengan makanan yang disajikan tersebut ${ }^{(2)}$.

Terdapat 9 macam jenis pelayanan gizi institusi, yaitu: penyelenggeraan makanan pada pelayanan kesehatan, anak sekolah (scholl feeding), asrama, institusi sosial, makanan khusus, industri transportasi, industri tenaga kerja, intitusi komersial dan penyelenggaraan makanan darurat ${ }^{(1)}$. Dalam suatu kegiatan penyelenggaraan makanan dalam jumlah yang besar pada institusi-institusi, terutama diperkotaan disebabkan oleh kurangnya ketersediaan waktu untuk menyediakan makanan bagi keluarga karena semakin banyaknya parawanita yang bekerja di luar rumah untuk memenuhi kebutuhan keluarga.Apabila manajemen pengelolaan gizi institusi baik maka pangan yang tersedia bagi seseorang atau sekelompok orang dapat tercukupi dengan baik pula. Oleh karena itu, adapun salah satu pelayanan penyelenggaraan makanan institusi yaitu penyelenggaraan makanan di sekolah yang dikelola oleh pengurus catering yang beranggotakan kaum wanita dengan tingkat pendidikan yang berbeda seperti lulusan tingkat SD dan tingkat SMA. Penyelenggaraan makanan di sekolah merupakan salah satu alternative yang dapat dilakukan untuk mengatasi suatu masalah yang berhubungan pada anak usia sekolah $\left.{ }^{(3}\right)$.

Oleh karena itu, penyelenggaraan makanan di sekolah ini bertujuan untuk memperbaiki status gizi terutama bagi anak sekolah yang tidak sempat sarapan dan membawa bekal, memperbaiki prestasi akademik, sebagai bahan pendidikan gizi untuk anak sekolah, dan membiasakan memilih makanan yang bergizi. Penyelenggaraan program makan siang di sekolah bagi anak-anak sekolah mengingat pentingnya masa pertumbuhan dan perkembangan bagi anak-anak sekolah dasar karena belum seluruhnya sekolah dasar dapat menerapkan penyelenggaraan makan siang di sekolah.

Sebagaimana kita ketahui dalam pelayanan makanan, tujuan yang ingin dicapai adalah kepuasan pelanggan. Kepuasan pelanggan sangat mempengaruhi keputusan untuk melakukan suatu pembelian kembali suatu produk ${ }^{(4)}$. Kepuasan konsumen adalah titik awal tumbuhnya loyalitas pelanggan sehingga penting untuk mengetahui penilaian terhadap kepuasan konsumen. Berdasarkan uraian tersebut dapat menunjukkan bahwa pentingnya penyelenggaraan makanan yang 
akan diterapkan oleh suatu institusi yang dapat memuaskan konsumen baik dari segi kualitas maupun kuantitasnya. Penyelenggaraan makanan terdiri dari beberapa komponen yaitu pembelian bahan makanan, penyimpanan bahan makanan, pengolahan makanan, penyajian makanan dan higiene sanitasi. besar porsi, dan kebersihan ${ }^{(5)}$.

Dari hasil penelitian yang dilakukan mengenai hubungan antara penampilan, rasa, dan cita rasa makanan dengan daya terima makan siang siswa di pusat pendidikan Artilleri Medan Cimahi, didapatkan hasil bahwa penilaian siswa terhadap penampilan makanan yang masih kurang, tetapi dari hasil uji statistik Chi Square menunjukan bahwa tidak ada hubungan antara penampilan makanan dengan daya terima makan siang ${ }^{(6)}$. sedangkan Hasil penelitian yang berbeda tetang tingkat kepuasan santri terhadap kualitas dan layanan makanan. Hasil penelitian tersebut menunjukkan bahwa: Tingkat kepuasan santri terhadap kualitas makanan di MBS Yogyakarta memperoleh skor rata-rata harapan 3,53 sedangkan kenyataan memperoleh skor ratarata 2,74 dengan kesenjangan $-0,79$ dan tingkat kesesuaian sebsesar $77,84 \%$. Skor tersebut termasuk dalam kategori tidak puas karena harapan lebih besar dari kenyataan ${ }^{(7)}$.

Di Kota Palu terdapat salah satu institusi yang menyelenggarakan makanan untuk anak sekolah, salah satunya adalah SMP Islam Terpadu Al-Fahmi berdiri pada Tahun 2015 bertempat di Jl. Gelatik No.88, Kelurahan Birobuli Utara, Kecamatan Palu
Selatan, Kota Palu, Provinsi Sulawesi Tengah. Pada tahun ajaran 2018/2019 siswa SMP Islam Terpadu Al-Fahmi berjumlah \pm 149 siswa. Dalam penyelenggaraan makanan SMPIslam Terpadu Al-Fahmi katering di bina langsung oleh Pembina Yayasan Al-Fahmi yang dibantu oleh dua orang pengarah. Kemudian dari pembina yayasan langsung dikelola oleh 3 pengelola yaitu pengelola I yang bertanggung jawab sebagai manager SDM, Perlengkapan, dan Kebersihan, pengelola II yang bertanggung jawab sebagai manager teknis, dan pengelola III yang bertanggung jawab sebagai konsultan gizi di katering SMP IT AlFahmi. Pengelola I dan II mengontrol dan mengatur bagian admisistrasi, logistik, olahan, distribusi, peralatan, dan sanitasi. Untuk bagian olahan makanan di awasi langsung oleh Mulyati yang bertanggung jawab dalam pengolahan lauk utama, lauk pendamping, nasi, sayur dan buah serta snack dimana pada proses pengolahan makanan tersebut dibantu oleh 16 orang penjamah makanan.Dalam manajemen sistem penyelenggaraan makanan di SMP Islam Terpadu Al-Fahmi perencenaan menu dilakukan oleh Ahli Gizi.Siklus menu yang digunakan adalah siklus menu 5 hari. Siklus menu tersebut digunakan untuk periode tertentu, tetapi sewaktu-waktu dapat dirubah berdasarkan permintaan klien (siswa). Menu makan siang yang di tetapkan di katering SMP IT Al-Fahmi adalah menu biasa dengan frekuensi hidangan makanannya $1 \mathrm{x}$ Snack dan 1 x makan utama. 
Berdasarkan uraian di atas, maka peneliti tertarik untuk melihat Tingkat kepuasan Pada Penyajian Menu Makan Siang Anak Sekolah Di SMP Islam Terpadu AlFahmi Kota Palu 2019.

\section{METODE PENELITIAN}

Jenis penelitian yang dilakukan adalah penelitian kuantitatif dengan pendekatan deskriptif bertempat di SMP Islam Terpadu Al-Fahmi pada bulan Juli 2019. Populasi dalam penelitian ini adalah siswa di SMP Islam Terpadu Al- Fahmi dengan memilih populasi semua siswa kelas 7 dan 8 diKota palu yang berjumlah 108 siswa. Sampel dalam penelitian ini adalah 95 siswa yaitu semua siswa kelas 7 dan 8 di SMP Islam Terpadu Al FahmiKota Palu. Pengumpulan data dilakukan dengan pengisian kuesioner oleh responden di SMP Islam Terpadu Al Fahmi Kota Palu. secara langsung dan menggunakan kuesioner yaitu dalam bentuk formulir kuesioner. Analisis data menggunakan analisis univariat.Analisis data dimulai dengan transkrip dan hasil wawancara mendalam. hasil penelitian disajikan dalam bentuk narasi.

\section{HASIL}

Rasa makanan dalam penelitian ini dibagi menjadi 2 kategori yaitu puas dan tidak puas. Sebanyak 87 orang (91.6\%) menyatakan puas dengan rasa makanan yang disajikan dan 8 orang $(8,4 \%)$ menyatakan tidak puas dengan rasa makanan yang disajikan. Sedangkan terhadap penampilan makanan menunjukan 85 orang $(89.5 \%)$ menyatakan puas dengan penampilan makanan yang disajikan dan 10 orang (10.5\%) menyatakan tidak puas dengan penampilan makanan yang disajikan (Tabel 1).

Tabel 1 Gambaran Kepuasan siswa berdasarkan rasa, penampilan, porsi, tingkat kematangan dan kebersihan makanan yang disajikan di sekolah SMP AlFahmi kota palu provinsi sulawesi tengah.

\begin{tabular}{|c|c|c|}
\hline Kepuasaan siswa & $\mathbf{f}$ & $\%$ \\
\hline \multicolumn{3}{|l|}{ Rasa makanan } \\
\hline Puas & 87 & 91.6 \\
\hline Tidak puas & 8 & 8.4 \\
\hline \multicolumn{3}{|l|}{ Penampilan } \\
\hline Puas & 85 & 89.5 \\
\hline Tidak puas & 10 & 10.5 \\
\hline \multicolumn{3}{|l|}{ Porsi makanan } \\
\hline Puas & 75 & 78.9 \\
\hline Tidak puas & 20 & 21.1 \\
\hline \multicolumn{3}{|c|}{ Tingkat Kematangan makanan } \\
\hline Puas & 90 & 94.7 \\
\hline Tidak puas & 5 & 5.3 \\
\hline \multicolumn{3}{|c|}{ Kebersihan makanan } \\
\hline Puas & 83 & 87.4 \\
\hline Tidak puas & 12 & 12.6 \\
\hline Total & 95 & 100,0 \\
\hline
\end{tabular}

dibagi menjadi 2 kategori yaitu puas dan tidak puas. Sebanyak 75 orang (78.9\%) menyatakan puas dengan porsi makanan yang disajikan dan 20 orang $(21.1 \%)$ menyatakan tidak puas dengan porsi makanan yang disajikan. Sedangkan terhadap tingkat kematangan makanan menunjukan bahwa 90 orang (94.7\%) menyatakan puas dengan tingkat kematangan makanan yang disajikan dan 5 orang (5.3\%) menyatakan tidak puas dengan tingkat kematangan makanan yang disajikan. Sementara itu kepuasan terhadap kebersihan makanan menunjukan sebanyak 83 orang (87.4\%) menyatakan puas dengan kebrsihan makanan yang disajikan dan 12 orang (12.6\%) 
menyatakan tidak puas dengan kebersihan makanan yang disajikan (Tabel 1).

\section{PEMBAHASAN}

a. Penilaian terhadap rasa

Rasa makanan dalam penelitian ini adalah kepuasan responden terhadap cita rasa menu makanan yang disajikan kepada responden.Dari hasil observasi rasa makanan di SMP Islam Terpadu Al-Fahmi Kota Palu sudah cukup bagus. Rasa makanan yang disajikan sudah sesuai sebanyak 87 siswa mengatakan puas dengan rasa makanan yang disajikan karena disekolah siswadiajarkan bagaimana cara bersyukur dengan apa yang diberikan dan siswa juga mengatakan bahwa makanannya enak,bumbunya pas dan beragam. sedangkandari 8 siswa yang tidak menyukai rasa makanan dikarenakan cita rasa makanan tidak seperti yang mereka harapkan (kurang enak/kurang garam).

b. Penilaian terhadap penampilan

$$
\text { Penampilan makanan dalam }
$$
penelitian ini adalah kepuasan responden terhadap variasi menu makanan yang disajikan kepada responden.Dari hasil observasi penampilan makanan di SMP Islam Terpadu Al-Fahmi Kota Palu sudah cukup bagus.Penampilan makanan yang disajikan sudah sesuai, sebanyak 85 siswa yangpuas dengan penampilan makanan yang disajikan karena siswa mengatakan penampilan makanan menarik dan tertata rapisedangkan dari 10 siswa yang tidak menyukai dikarenakan makanan yang disajikan setiap hari hampir sama sehingga siswa merasa bosan dengan penampilan makanan yang disajikan .

c. Porsi makanan yang disajikan

Porsi makanan dalam penelitian ini adalah kepuasan responden terhadap banyaknya porsi makanan yang disajikan kepada responden.Dari hasil observasi porsi makanan di SMP Islam Terpadu Al-Fahmi Kota Palu sudah cukup bagus. Porsi makanan yang disajikan sudah sesuai, 75 siswa yang menyatakan puas dengan porsi makanan yang disajikan karena makananan yang disediakan cukup banyak sehingga sebagian besar siswa bebas mengambil makanannya dan bisa menambah makanan jika makanan yang disediakan berlebih sedangkan dari 20 siswa tidak merasa puas dikarenakan responden kadang tidak mendapat jatah makanan dan kadang juga lauknya tidak sesuai porsi (sedikit).

d. Tingkat kematangan makanan yang disajikan

Tingkat kematangan makanan dalam penelitian ini adalah kepuasan responden terhadap kematangan makanan yang disajikan kepada responden.Dari hasil observasi tingkat kematangan makanan di SMP Islam Terpadu AlFahmi Kota Palu sudah cukup bagus. Tingkat kematangan makanan yang disajikan sudah sesuai, 90 siswa puas dengan tingkat kematangan pada makanan disajikan karena siswa mengatakan 
tingkat kematangan yang siswa rasakan sudah memenuhi harapan siswa (pas,tidak kurang dan tidak lebih)sedangkan 5 siswa yang tidak menyukai dikarenakan responden pernah mendapatkan makanan yang disajikan kurang matang.

e. Kebersihan makanan yang disajikan

Kebersihan makanan dalam penelitian ini adalah kepuasan responden terhadap kebersihan makanan yang disajikan kepada responden.Dari hasil observasi kebersihan makanan di SMP Islam Terpadu Al-Fahmi Kota Palu sudah cukup bagus. kebersihan makanan yang disajikan sudah sesuai, 83 siswa puas dengan kebersihan makanan yang disajikan karena semua makanan yang disajikan terjaga kebersihannyasedangkan 12 siswa yang tidak merasa puas dikarenakan responden pernah mendapatkan makanan yang disajikan kurang higienes seperti didalam makanan terdapat rambut, kerikil-kerikil kecil dalam makanan dll.

\section{KESIMPULAN DAN SARAN}

Kesimpulan dari penelitian ini adalah responden merasa puas terhadap makanan yang disajikan di SMP Islam Terpadu AlFahmi Kota Paluri. Saran dari penelitian ini sebaiknya dibuatkan ruang makan siswa dan membagi porsi makanan Agar semua siswa mendapatkan porsi makanan yang sama rata.

\section{UCAPAN TERIMA KASIH}

Terima kasih kepada 1) Direktur Poltekkes Kemenkes Palu, 2) Kepala Yayasan
SMP IT Al Fahmi Kota Palu, 3) Kepala

Sekolah SMP IT Al Fahmi Kota Palu

\section{DAFTAR PUSTAKA}

1. Kemenkes. PGRS. Pedoman PGRS Pelayanan Gizi Rumah Sakit. 2013;

2. Wulansari A, Setiawan B, Sinaga T. Penyelenggaraan Makanan Dan Tingkat Kepuasan Konsumen Di Kantin Zea Mays Institut Pertanian Bogor. J Gizi dan Pangan. 2014;

3. Utami AT. Studi Evaluasi Penyelenggaraan Makan Siang di Sekolah. Vol. 84. 2013. 487-492 p.

4. Taqhi SA. PONDOK PESANTREN HUBULO GORONTALO The Description of Food Procurement Systemat the Hubulo Islamic. Media Kesehat Masy Indones. 2014;

5. Kustiyoasih MP, Adriani M, Nindya TS. Penyelenggaraan Makanan Dan Kepuasan Konsumen Di Kantin Lantai 2 Rumah Sakit Universitas Airlangga Surabaya. Media Gizi Indones. 2017;11(1):11.

6. Anggun PC. Hubungan antara penampilan, rasa, dan cita rasa makanan dengan daya terima makan siang siswa di Pusat Pendidikan Artileri Medan (Pusdik Armed) Cimahi. 2011;

7. Rahmawati N. Tingkat Kepuasan Santri Terhadap Kualitas Dan Layanan Makanan Di Muhammadiyah Boarding School Yogyakarta. 2018; 